Historic, archived document

Do not assume content reflects current scientific knowledge, policies, or practices. 



\begin{tabular}{|l}
\hline UNITED STATES DEPARTMENT OF AGRICULTURE \\
\hline DEPARTMENT BULLETIN No. 1310 \\
\hline Washington, D. $\mathrm{C}$. \\
Dontana Agricultural Experiment Station
\end{tabular}

\section{EXPERIMENTS WITH FALLOW IN NORTH-CENTRAL MONTANA}

By George W. Morgan, Associate Agronomist, Office of Dry-Land Agriculture Investigations, Bureau of Plant Industry

\section{CONTENTS}

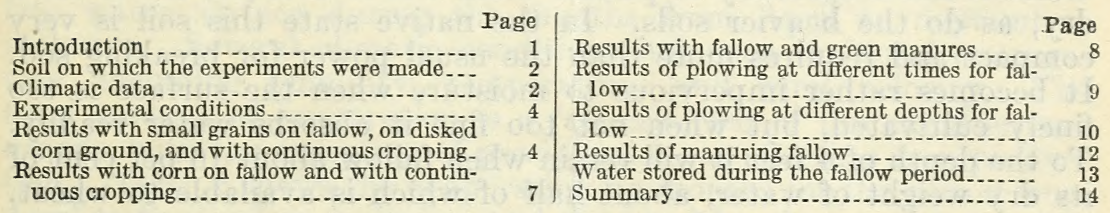

\section{INTRODUCTION}

This bulletin presents the results of experiments with summer fallow during the seven years from 1917 to 1923, inclusive, at the Assinniboine Field Station, located 8 miles southwest of Havre, Mont. The results are printed as a report of progress rather than as giving final or definite conclusions. Throughout the period of the experiments, except possibly in 1923, climatic conditions were abnormally unfavorable to crops. A careful analysis of the climatic records for the 44-year period from 1880 to 1923 , inclusive, shows that the last seven years are representative of the most unfavorable conditions to be expected rather than of the average.

Land that lies over the season in a cultivated condition without being cropped is known as summer fallow, fallow, or summer tillage. It is confined largely to arid and semiarid regions and is seldom found in humid sections or on irrigated land.

Summer fallow has been used more generally in the intermountain valleys and certain farming sections between the Rocky and the Sierra Nevada Mountains than it has on the Plains east of the Rocky Mountains. West of these mountains the precipitation falls mostly during the winter either as slow and continued rain or as snow. At this time evaporation is low, and a large percentage of the water is stored in the soil. In the Plains east of the mountains more than 70 per cent of the precipitation comes during the growing season. It may come in the form of light and scattered showers, with the result that the water is largely lost by evaporation; it may come in torrential rains with a heavy loss by run-off; or it may come in slow continued $10210^{\circ}-25 \dagger-1$ 
rains, of which a large proportion is stored in the soil. A larger percentage of the average precipitation is lost in the Plains region owing to the larger amount of evaporation in the summer than in the mountains west.

During the seven years of these experiments there were many crop failures in the northern Great Plains. These failures were not only on land that was cropped each year but also on land that was fallowed the previous year. The history of these fallow fields shows that the methods of managing fallow have varied greatly, no definite plan being generally followed in this region.

\section{SOIL ON WHICH THE EXPERIMENTS WERE MADE}

The soil on which the experiments were conducted is unirrigated bench land with an altitude of approximately 2,600 feet and is representative in general of that portion of central northern Montana having an altitude of 2,000 to 3,000 feet.

This soil is classed as sandy clay loam and is of glacial origin. While it has a tendency to puddle when wet it does not crack when dry, as do the heavier soils. In the native state this soil is very compact and requires more than the usual power for breaking sod. It becomes rather impervious to moisture when the surface is too finely cultivated, but when not too fine it absorbs water readily. To the depth of 4 feet it will retain when fallow about 16 per cent of its dry weight of water, about half of which is available to wheat. This means approximately 5 inches of water.

\section{CLIMATIC DATA}

\section{PRECIPITATION}

The precipitation for each of the 5 months from April to August, the total precipitation for that period, and the annual precipitation for each of the 7 years from 1917 to 1923, inclusive, are shown in Table 1. The precipitation during the 7 years under study was below normal. The average precipitation for the 44 years from 1880 to 1923, inclusive, was 13.33 inches, but for the 7 years it was only 11.26 inches. The 44-year normal for the 5 months from April to August was 8.58 inches, whereas the average for these months for the 7-year period from 1917 to 1923, inclusive, was 7.17 inches. In each of the years 1917, 1918, and 1919 the total for the 5 months was less than 5 inches. In 1920, 1921, and 1922 the total was more nearly normal, and in 1923 it was 4.13 inches above the normal. The 7-year monthly averages were below the 44-year normals for all months except April, for which it was 0.03 inch above the normal.

It is recognized that the distribution of precipitation during the growing season is an important factor in crop production. Yields of grain are strongly influenced by the amount and distribution of the June rainfall. In each of the 7 years under study except 1923 the precipitation in June was below the 44-year normal for that month. In 1922 the seasonal precipitation was about normal, but the June precipitation was much below normal, and the resulting injury to crops was severe. 
TABLE 1.-Monthly precipitation for April to August, inclusive, and the total annual precipitation, 1917 to 1923 , inclusive

\begin{tabular}{|c|c|c|c|c|c|c|c|}
\hline \multirow{2}{*}{ Year } & \multicolumn{7}{|c|}{ Precipitation (inches) } \\
\hline & April & May & June & July & August & $\begin{array}{c}\text { Seasonal, } \\
\text { April to } \\
\text { August }\end{array}$ & Annual \\
\hline $\begin{array}{l}1917 \\
1918 \\
1919 \\
1920 \\
1922 \\
1923\end{array}$ & $\begin{array}{r}0.86 \\
.44 \\
.31 \\
1.71 \\
.80 \\
1.43 \\
.78\end{array}$ & $\begin{array}{l}0.42 \\
.08 \\
1.09 \\
1.39 \\
2.83 \\
2.37 \\
1.93\end{array}$ & $\begin{array}{l}1.59 \\
1.51 \\
1.99 \\
2.20 \\
2.68 \\
.90 \\
4.86\end{array}$ & $\begin{array}{r}0.43 \\
.74 \\
.19 \\
1.36 \\
2.16 \\
1.90 \\
3.65\end{array}$ & $\begin{array}{r}0.70 \\
2.10 \\
.60 \\
1.26 \\
.53 \\
.92 \\
1.49\end{array}$ & $\begin{array}{r}4.00 \\
4.87 \\
4.18 \\
7.92 \\
9.00 \\
7.52 \\
12.71\end{array}$ & $\begin{array}{r}11.86 \\
8.55 \\
7.56 \\
11.20 \\
13.37 \\
10.26 \\
16.03\end{array}$ \\
\hline 7-year average & .90 & 1.44 & 2. 25 & 1.49 & 1. 09 & 7.17 & 11. 26 \\
\hline
\end{tabular}

\section{EVAPORATION}

Daily measurements have been made of the evaporation from a free water surface during the months from April to September, inclusive. Several climatic conditions influence the total evaporation, including humidity, temperature, and wind velocity. The total amount of evaporation is a fair criterion of the climatic conditions, with the exception of precipitation, as affecting crop production. Table 2 shows the evaporation by months for the period from April to September, inclusive, and the total for the years from 1917 to 1923 , inclusive, with the 7-year average for each month and for the entire period.

The average seasonal evaporation for the seven years was 36.182 inches. The total evaporation for 1919 was the highest for the period. This was the year of lowest rainfall. The evaporation for 1921 was almost as high as for 1919, although the rainfall during the growing season was nearly normal. The highest evaporation is in July, the average for this month being nearly 1 inch more than for either June or August, which are the next highest. The total for July was over 9 inches in 1917 and 1919. The evaporation for July and August was unusually low in 1923.

TABLE 2.-Monthly evaporation for A pril to September, inclusive, 1917 to 1923, inclusive

\begin{tabular}{|c|c|c|c|c|c|c|c|}
\hline \multirow{2}{*}{ Year } & \multicolumn{7}{|c|}{ Evaporation (inches) } \\
\hline & April & May & June & July & August & $\begin{array}{l}\text { Septem- } \\
\text { ber }\end{array}$ & Total \\
\hline $\begin{array}{l}1917 \\
1918 \\
1919 \\
1920 \\
1921 \\
1922 \\
1923\end{array}$ & $\begin{array}{l}2.578 \\
4.678 \\
4.314 \\
2.374 \\
\text { 4. } 054 \\
2.783 \\
4.628\end{array}$ & $\begin{array}{l}5.533 \\
6.118 \\
6.460 \\
6.889 \\
5.294 \\
5.325 \\
6.648\end{array}$ & $\begin{array}{l}6.091 \\
8.390 \\
7.659 \\
6.795 \\
7.024 \\
6.936 \\
6.333\end{array}$ & $\begin{array}{l}9.518 \\
7.311 \\
9.440 \\
8.210 \\
8.734 \\
6.965 \\
5.827\end{array}$ & $\begin{array}{l}7.033 \\
6.291 \\
7.646 \\
7.744 \\
8.306 \\
7.229 \\
4.945\end{array}$ & $\begin{array}{l}3.885 \\
3.685 \\
4.461 \\
4.973 \\
4.890 \\
5.152 \\
4.124\end{array}$ & $\begin{array}{l}34.638 \\
36.473 \\
39.980 \\
36.985 \\
38.302 \\
34.390 \\
32.505\end{array}$ \\
\hline 7-year average & 3. 630 & 6. 038 & 7. 033 & 8.001 & 7. 028 & 4.453 & 36.182 \\
\hline
\end{tabular}




\section{EXPERIMENTAL CONDITIONS}

The results which are here reported were obtained on tenth-acre plats which are 2 rods wide by 8 rods long with alleys 4 feet wide between the plats and roadways 20 feet wide at the ends. Ordinary farm machinery was used in working the land, and the various operations were as nearly like those of good field practice as possible. The plowing, unless otherwise noted, was 7 to 8 inches deep. The fallow land was plowed the latter part of May except in one set of plats included in the time-of-plowing test. The fall plowing for grain the following year was done as soon as there was sufficient moisture to work the land after the crop was removed. The spring plowing for grain was done as early as the soil conditions permitted.

The cultivation after plowing fallow was about the same from year to year. It was not excessive, but was intended to accomplish the following purposes: (1) To prevent the loss of moisture from the soil, mainly by preventing weed growth and also possibly decreasing the evaporation from the surface foot of soil; (2) to maintain a coarse granular mulch that would not blow and would absorb as much of the precipitation as possible; and (3) to prepare a seed bed in which the crop would germinate readily and make a good early growth.

Fallow land other than that fall plowed was cultivated once soon after plowing. This cultivation was with either a disk set straight or with a spike-tooth harrow. Two or three cultivations were given after this with a weeder, a spring-tooth harrow, or a duck-foot cultivator. The early cultivations were thorough, in order to kill all weed growth, the weeder being generally used for this purpose, while the last cultivation was such as to leave the immediate surface somewhat ridged and granular. The duck-foot cultivator was the implement used for this last cultivation.

Land that was fall plowed for a crop the following year was left rough during the winter. A double disking and a double harrowing just before seeding were necessary in preparing a seed bed. Land spring plowed for immediate cropping was cultivated soon after plowing. A double disking and a harrowing were generally given, although at times a spring-tooth harrow replaced the disk.

Standard varieties of each crop were grown, with no change in varieties during the period here reported. The following are the varieties and rates of seeding per acre: Spring wheat, Peliss, 1 bushel; oats, Sixty-Day, 11/2 bushels; barley, White Smyrna, 11/2 bushels; and corn, Northwestern Dent, surface planted in drills 44 inches apart with the plants approximately 18 inches in the row. In all cropping tests there were enough plats so that a crop was grown by each method each year.

\section{RESULTS WITH SMALL GRAINS ON FALLOW, ON DISKED CORN GROUND, AND WITH CONTINUOUS CROPPING}

The yields of spring wheat, oats, and barley grown on fallow are compared with those grown on disked cornland and those on continuous grain. The yield given for each method is the average of several plats. Some of the yields on fallow are from alternate fallow and cropping, and some are from fallow in 3-year and 4-year rotations. To date, there has been little difference between the yields of a crop 
which alternates with fallow and those obtained on fallow in rotations where fallow appears less frequently. The yields given for continuous cropping are the averages for all plats continuously cropped to any grain, regardless of the methods used in preparing the seed bed. For example, the average for continuously cropped spring wheat is the average of all plats on which spring wheat was grown every year, although these plats had different cultural treatments in that some were fall plowed and some were spring plowed. There was also a difference in the depth of plowing, but the depth has made no consistent difference in the yield where the crop was grown continuously.

Table 3 gives the annual and average yields of spring wheat, oats, and barley on fallow, on disked corn ground, and with continuous cropping for the seven years from 1917 to 1923, inclusive. For these years spring wheat averaged 12.4 bushels on fallow, 9.2 bushels on disked corn ground, and 5.7 bushels with continuous cropping; oats averaged 23 bushels on fallow, 16.7 bushels on disked corn ground, and 12.6 bushels with continuous cropping; and barley averaged 16.1 bushels on fallow, 10.7 bushels on disked corn ground, and 6.8 bushels with continuous cropping. The different tillage methods had the same relative values-for the three crops, the yields on fallow being highest, those on corn ground second, and those under continuous cropping the lowest. In 1919, a year of generally poor yields, the yield on corn ground was higher than on fallow. With this exception the relation between the three methods was quite consistent from year to year. For spring wheat, cornland compared most favorably with fallow in 1918, 1919, and 1920 and least favorably in 1922, when the yields from cornland were relatively low, being even lower than those on continuous cropping.

The highest yields of oats were on fallow in all years except 1919, when all yields were very light and the yields on cornland were relatively high. The highest yields of barley were on fallow with the one exception of 1919 .

The yields of wheat, oats, and barley with the three distinct preparations, as presented in Table 3, are shown graphically in Figures 1, 2 , and 3 .

TABLE 3.-Yields of spring wheat, oats, and barley on fallow, disked corn ground, and with continuous cropping, 1917 to 1923, inclusive

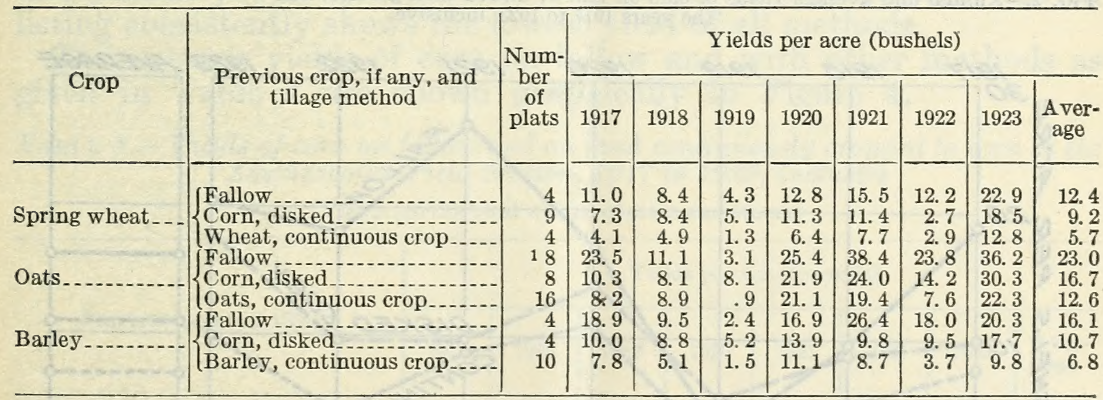

1 Nine plats in 1919 and after. 


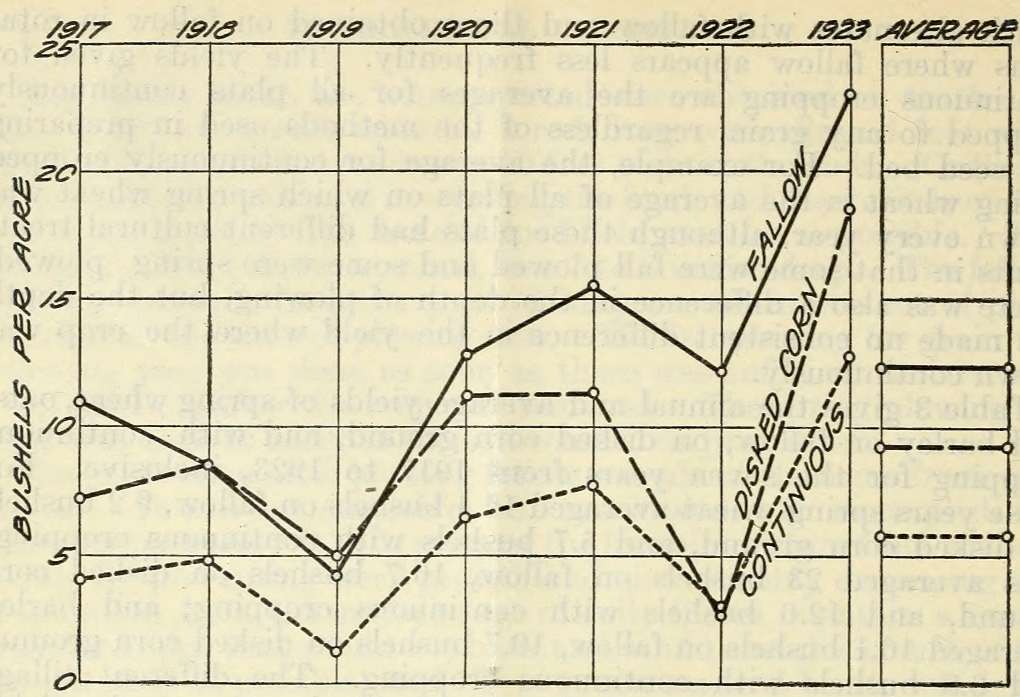

Fig. 1.-Annual and average yields of spring wheat on fallow, disked corn ground, and with continuous wheat for the years 1917 to 1923 , inclusive

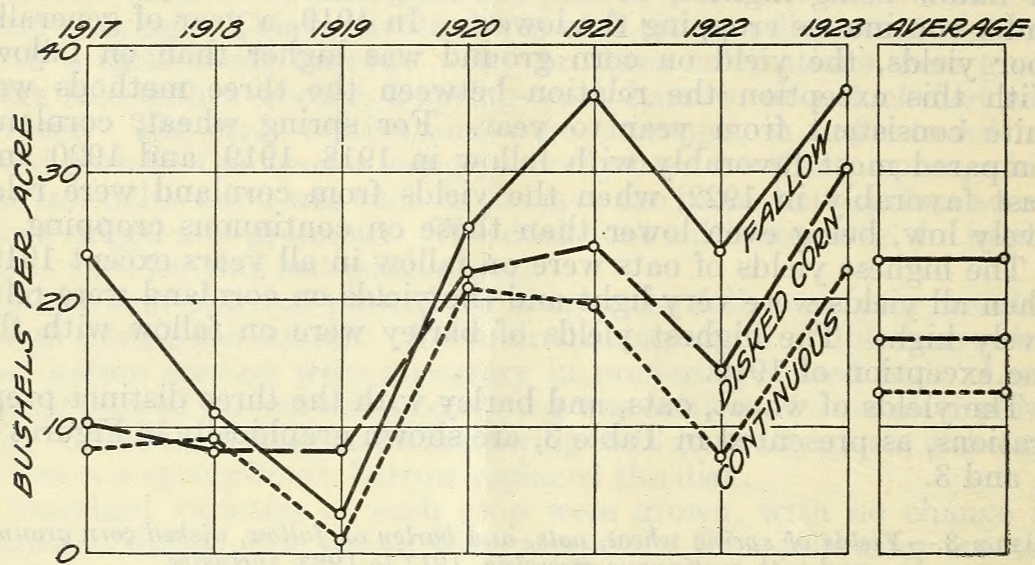

Fig. 2.-Annual and average yields of oats on fallow, disked corn ground, and with continuous oats for the years 1917 to 1923 , inclusive

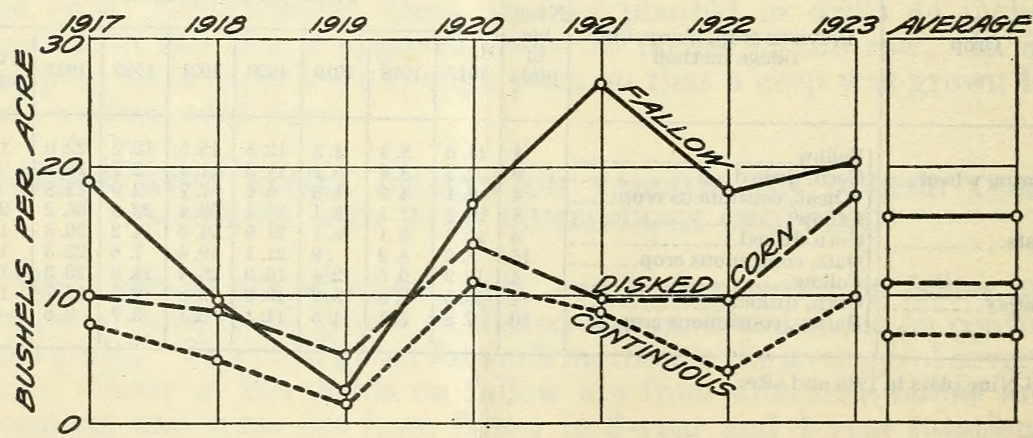

FIG. 3.-Annual and average yields of barley on fallow, disked corn ground, and with continuous barley for the years 1917 to 1923 , inclusive 


\section{RESULTS WITH CORN ON FALLOW AND WITH CONTINUOUS CROP- PING}

Four plats are cropped to corn continuously. One is on 4-inch spring plowing, one on 8-inch fall plowing, one on 8-inch fall plowing with subsoiling to a depth of 18 inches for 1917, 1919, and 1920, and one on spring listing. Another plat of corn is grown each year on fallow. This requires two plats, one in fallow and one in corn.

The yields of these five plats for the seven years from 1917 to 1923 , inclusive, are shown in Table 4 . The yields given are the total pounds per acre of grain and stover. Some grain is produced in most years, but the grain is often immature, owing to drought. In 1918 and 1923 all plats produced good grain, but to make the different years comparable the yields are given as the totals. Corn as it is grown in this locality at the present time is a feed for farm consumption and is fed largely as fodder.

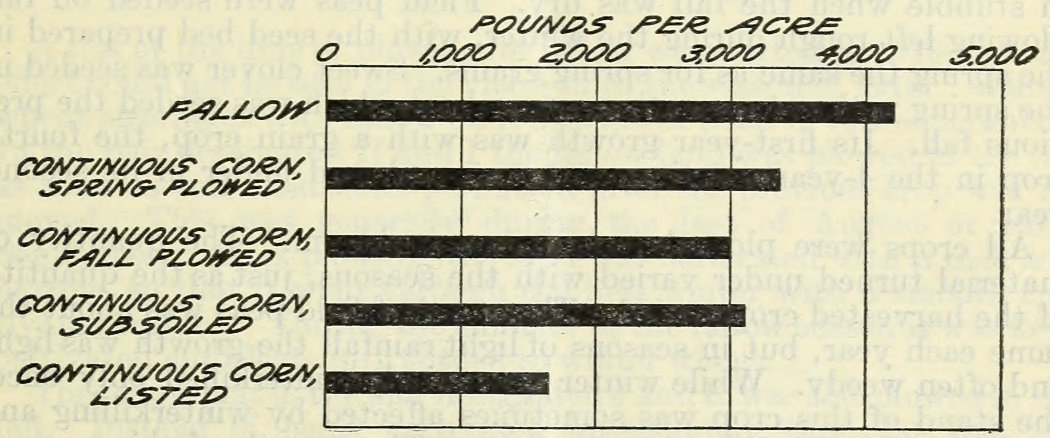

Fig. 4.-A verage yields of corn on fallow and with four methods of continuous cropping to corn for the 7-year period from 1917 to 1923 , inclusive

The average yield of corn after fallow was 4,199 pounds, which was 848 pounds more than that of continuous corn on spring plowing. Spring plowing was the highest yielding of the tillage methods for continuous corn and showed a decided advantage over all methods in 1919. It also showed a higher yield than fall plowing in four of the seven years. The average yield from subsoiling was about 100 pounds more than from 8-inch fall plowing. This difference is small and probably within the limits of error in the experiment. Spring listing consistently shows the lowest yield of all methods.

The average yields of corn on fallow and with other methods as given in Table 4 are shown graphically in Figure 4.

TABLE 4.-Yields of corn on fallow and on land continuously cropped to corn at the Assinniboine Field Station, 1917 to 1923, inclusive

[Yields are the total weight of grain and stover]

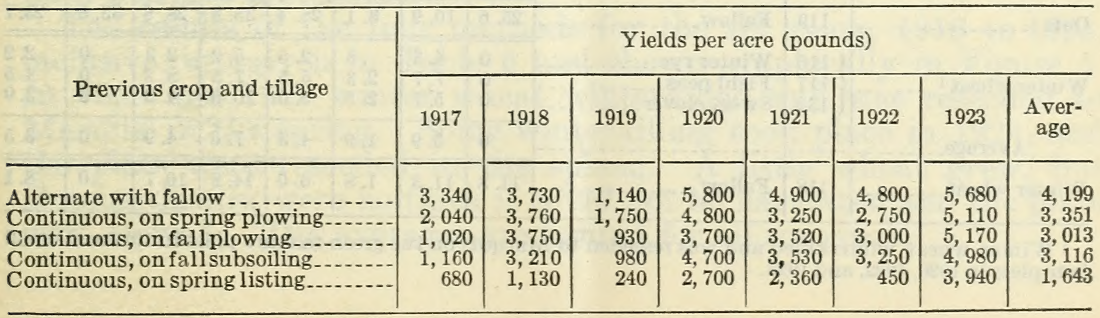




\section{RESULTS WITH FALLOW AND GREEN MANURES}

Rotations including fallow and green manures were started in 1916. As the green manures are modified fallows, in that the crops are turned under before maturity and the ground then treated as fallow for the remainder of the season, the results are presented for comparison. In the series of rotations offering these comparisons the fallow and the green manures each occur in 4-year rotations. In one group of these rotations the fallow and green manures are followed by winter wheat, and in another group they are followed by oats. In both groups the third crop is corn, and the fourth crop is oats where winter wheat precedes the corn and winter wheat where oats precede it.

The crops grown for green manure were winter rye, field peas, and biennial sweet clover. Winter rye was seeded on fall plowing when the conditions were favorable for plowing in the fall and was drilled in stubble when the fall was dry. Field peas were seeded on fall plowing left rough during the winter, with the seed bed prepared in the spring the same as for spring grains. Sweet clover was seeded in the spring with oats or with winter wheat which was seeded the previous fall. Its first-year growth was with a grain crop, the fourth crop in the 4-year rotation, and it was plowed under in its second year.

All crops were plowed under when in bloom. The quantity of material turned under varied with the seasons, just as the quantity of the harvested crop varied. The stand of field peas was about the same each year, but in seasons of light rainfall the growth was light and often weedy. While winter rye entirely winterkilled only once, the stand of this crop was sometimes affected by winterkilling and varied somewhat from year to year. The growth of this crop at the time it was plowed under varied from 18 to 42 inches in height. Weed growth in winter rye was very light. Sweet clover either failed to survive the first summer or winterkilled, so that the stands were generally thin and the growth for turning under light.

TABLE 5.-Annual and average yields of oats and winter wheat on fallow and green manures, 1917 to 1923, inclusive

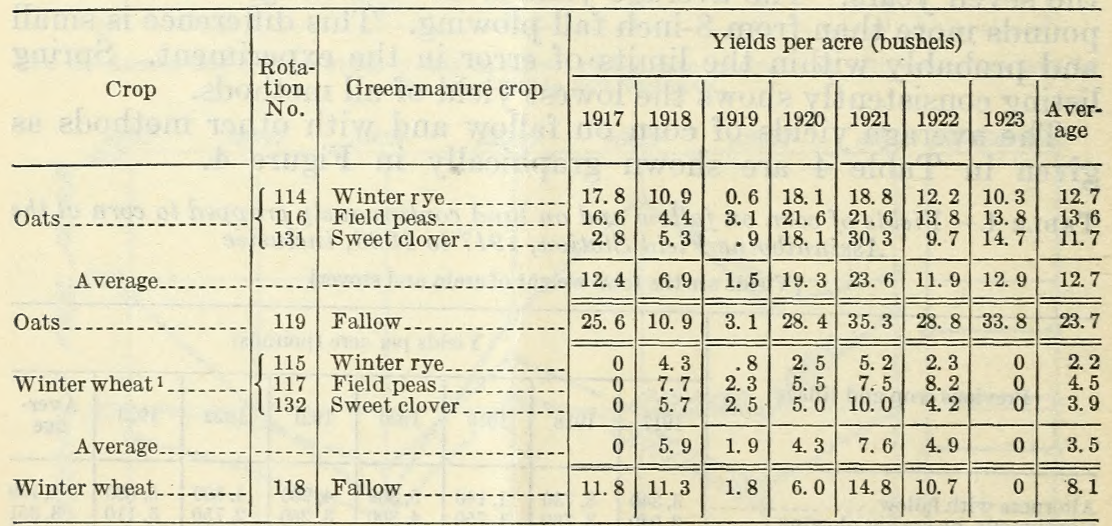

1 Winter wheat winterkilled and was reseeded to Marquis on the green-manure plats in 1917 and on all four plats in 1920, 1922, and 1923. 
The results reported are for the crop immediately following the fallow or the green manures. No marked effects have yet been evidenced on succeeding crops, but as the experiment progresses or with more favorable seasons the results may become more clear.

Table 5 gives the annual and average yields of winter wheat and oats following fallow and the three green manures in comparable rotations for the seven years, 1917 to 1923, inclusive. No great difference is evidenced between the three green manures as preparations for either oats or winter wheat, although field peas appear to have a slight advantage over the other two. Between the green manures and the fallow there is a marked difference, the yields on green manure being about doubled on fallow.

As the cost of green manure is much higher than that of fallow, its use is a much less profitable practice.

\section{RESULTS OF PLOWING AT DIFFERENT TIMES FOR FALLOW}

A test of the time of plowing for fallow was started in 1916, but the effect could not be seen in the yields until the season of 1918. Winter wheat alternates with fallow on four pairs of plats in this experiment. In the pair designated $\mathrm{H}$ and $\mathrm{I}$ the fallow land was plowed in the fall as soon as soil conditions permitted after the previous crop was removed. This was generally during the last of August or early September. After plowing, the land was cultivated with a disk and harrow, so that it went through the first winter with a smooth cultivated surface. During the summer of the fallow season it was kept cultivated and clean until seeded to winter wheat.

The fallow plat in the pair designated $J$ and $\mathrm{K}$ was also plowed in the fall. Instead of being cultivated immediately this plat was left rough during the first winter. During the following summer it was kept cultivated, the same as the fallow just described.

The fallow plat in the pair lettered $\mathrm{L}$ and $\mathrm{M}$ was plowed in May. There was no cultivation before plowing; after plowing there was sufficient to control weeds.

The fallow plat in the pair designated $\mathrm{N}$ and $\mathrm{O}$ was plowed the last of June or early in July with no previous cultivation. Weeds and volunteer grain made a fair growth before this plat was plowed. Sufficient cultivation to prepare a good seed bed was given after plowing.

The four fallows varied in the time of plowing and in the cultivation that was given after plowing. Two were plowed in the fall and differentiated by working one down smooth at once, while the other went through the winter rough, as left by the plow. The other two went through the first winter in stubble. One was plowed early, before weeds had made much growth, and the other was not plowed until well into the summer.

The results of the four methods for the six years, 1918 to 1923, inclusive, are given in Table 6 and shown graphically in Figure 5. In 1920 and 1922 winter wheat winterkilled and was reseeded to Marquis in the spring. Some winterkilling took place in 1923, and the plats were reseeded in the spring. A little wheat grew, but Russianthistles were so thick it could not be harvested and the plats were mowed. The averages are figured for all six years. 
With the unfavorable seasons and the failures of winter wheat the yields with all methods are low, but marked differences are shown between them.

TABLE 6.-Annual and average yields of winter wheat ${ }^{1}$ obtained with four methods of fallow, 1918 to 1923, inclusive

\begin{tabular}{|c|c|c|c|c|c|c|c|c|}
\hline \multirow{2}{*}{ Plats } & \multirow{2}{*}{ Treatment } & \multicolumn{7}{|c|}{ Yields per acre (bushels) } \\
\hline & & 1918 & 1919 & 1920 & 1921 & 1922 & 1923 & Average \\
\hline $\mathrm{H}$ and $\mathrm{I}$ & Fall plowed; cultivated immedi- & 6.0 & 10.3 & 3.8 & 13.2 & 3.5 & 0 & 6.1 \\
\hline $\mathbf{J}$ and $\mathbf{K}$ & Fall plowed; left rough first & 5.5 & 15.3 & 8.0 & 15. 7 & 9.5 & 0 & 9.0 \\
\hline $\begin{array}{l}\mathrm{L} \text { and } \mathrm{M} \\
\mathrm{N} \text { and } \mathrm{O}_{-}\end{array}$ & $\begin{array}{l}\text { Spring plowed (May) } \\
\text { Summer plowed (early July) }\end{array}$ & $\begin{array}{l}7.2 \\
4.5\end{array}$ & $\begin{array}{c}10.7 \\
0\end{array}$ & $\begin{array}{l}6.8 \\
2.7\end{array}$ & $\begin{array}{r}16.8 \\
7.5\end{array}$ & $\begin{array}{r}13.0 \\
4.2\end{array}$ & $\begin{array}{l}0 \\
0\end{array}$ & $\begin{array}{l}9.1 \\
3.2\end{array}$ \\
\hline
\end{tabular}

1 In 1920 and 1922 winter wheat winterkilled and was reseeded to Marquis. Some winterkilling took place in 1923, and the plats were reseeded in the spring.

Fall plowing which was cultivated after plowing shows 2.9 bushels less yield than fall plowing left rough during the first winter. The yield from fall plowing left rough is about equal to that of May plowing. These two methods show rather consistently higher yields than the other two. The most outstanding contrast in methods is between the May plowing and the early July plowing, the average yield from the latter being only slightly more than one-third that from the former.

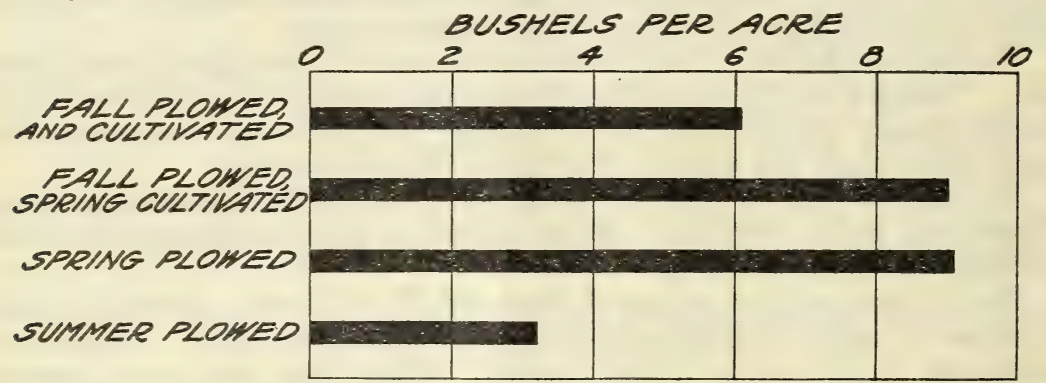

FIG. 5. - 1 A verage yields of winter wheat with four methods of fallow for the 6-year period from 1918 to 1923, inclusive

\section{RESULTS OF PLOWING AT DIFFERENT DEPTHS FOR FALLOW}

Depth-of-plowing experiments were started in 1916, and the results for seven years of plowing fallow at different depths are here reported. The depths of plowing were 4, 8, and 18 inches including subsoiling to a depth of 10 inches below the plowed furrow. In the latter case, only the surface 8 inches was turned by plowing, the lower 10 inches being loosened by means of a subsoiler.

Oats, barley, and winter wheat have been grown each year on fallow plowed to the depths specified. Neither the depths of plowing nor the crops have been changed during the 7-year period. The plowing was done in May and sufficient summer cultivation given to control weed growth and maintain a clod mulch. The plats plowed to a depth of 8 inches agree in method with the plats $L$ and $M$ in the last described experiment. 
The annual and average yields of the three crops on fallow plowed to different depths for the seven years, 1917 to 1923, inclusive, are given in Table 7 and shown graphically in Figure 6.

TABLE 7.-Annual and average yields of oats, barley, and winter wheat on fallow plowed at different depths, 1917 to 1923, inclusive

\begin{tabular}{|c|c|c|c|c|c|c|c|c|c|}
\hline \multirow{2}{*}{ Crop } & \multirow{2}{*}{$\begin{array}{l}\text { Depth of } \\
\text { plowing }\end{array}$} & \multicolumn{8}{|c|}{ Yields per acre (bushels) } \\
\hline & & 1917 & 1918 & 1919 & 1920 & 1921 & 1922 & 1923 & A verage \\
\hline Winter wheat ${ }^{1}$ & $\left\{\begin{array}{l}4 \text { inches } \\
8 \text { inches } \\
18 \text { inches } \\
4 \text { inches } \\
8 \text { inches } \\
18 \text { inches } \\
4 \text { inches } \\
8 \text { inches... } \\
18 \text { inches. }\end{array}\right.$ & $\begin{array}{r}21.6 \\
23.1 \\
24.1 \\
16.3 \\
18.8 \\
21.9 \\
\hdashline\end{array}$ & $\begin{array}{r}7.5 \\
10.3 \\
13.4 \\
6.0 \\
9.4 \\
12.1 \\
7.7 \\
10.8 \\
10.5\end{array}$ & $\begin{array}{l}1.6 \\
1.6 \\
1.7 \\
1.8 \\
2.1 \\
1.7 \\
1.0 \\
.7 \\
.7\end{array}$ & $\begin{array}{r}20.3 \\
26.9 \\
34.1 \\
18.8 \\
17.1 \\
17.3 \\
4.3 \\
6.7 \\
8.0\end{array}$ & $\begin{array}{l}34.1 \\
43.8 \\
46.6 \\
22.7 \\
34.8 \\
33.3 \\
12.3 \\
14.8 \\
11.8\end{array}$ & $\begin{array}{r}21.6 \\
26.3 \\
27.8 \\
19.2 \\
20.2 \\
19.0 \\
9.7 \\
12.0 \\
13.8\end{array}$ & $\begin{array}{l}30.3 \\
40.0 \\
39.7 \\
20.2 \\
25.0 \\
20.2 \\
0 \\
0 \\
0\end{array}$ & $\begin{array}{r}19.6 \\
24.6 \\
26.8 \\
15.0 \\
18.2 \\
17.9 \\
5.8 \\
7.5 \\
7.5\end{array}$ \\
\hline
\end{tabular}

1 Winter wheat winterkilled in 1920 and 1922 and was reseeded to Marquis. It partly winterkilled in 1923 and was reseeded to Marquis, but it was too weedy to harvest.

The yield of oats was generally increased by increasing the depth of plowing, with the difference between the 4-inch and the 8-inch plowing much more pronounced than that between the latter depth and subsoiling to 18 inches. The average yield from 4-inch plowing for fallow was 19.6 bushels per acre and from 8-inch plowing 24.6 bushels, an increase of 5 bushels on the greater depth. The average yield on subsoiling to a depth of 18 inches in plowing for fallow was 26.8 bushels, an increase of 2.2 bushels over 8-inch plowing. This increase in yield was not sufficient to pay for the greater cost of the subsoiling.

Barley was not as consistent as oats in its response to the different depths of plowing. During the first two years of the

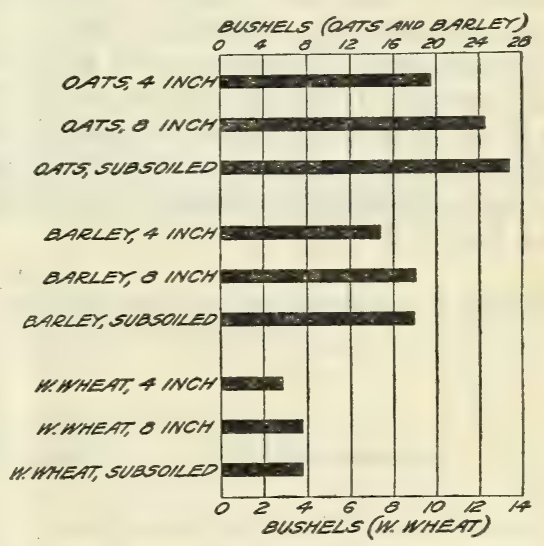

FIG. 6.-Average yields of oats, barley, and winter wheat on 4-inch plowing, 8-inch plowing, and subsoiling to a depth of 18 inches for the 7 -year period from 1917 to 1923, inclusive

experiment subsoiling showed the highest yields; in 1920 the 4-inch plowing gave the highest yield, and in the other four years the 8-inch plowing resulted in the largest returns. The averages for the period show an increase of 3.2 bushels per acre for the 8-inch plowing over the average of 15 bushels for the 4-inch plowing. The average yield from the subsoiling was 0.3 bushel less than from the 8-inch plowing.

The winter-wheat yields have not been satisfactory in that this crop winterkilled in 1920, 1922, and 1923. The thin stand in other years and in the reseeded crop in these years allowed Russianthistles to grow profusely. The heavy growth of thistles decreased the yields very noticeably in all years. 


\section{RESULTS OF MANURING FALLOW}

The effect of an application of barnyard manure has been tested in two comparisons with winter wheat and one with oats. The manure is applied at the rate of approximately 10 tons per acre before the land is plowed for fallow. Rotation 38 is alternate winter wheat and fallow with manure, and plats C and D in the continuous-cropping series are alternate winter wheat and fallow without manure. Rotations Nos. 118 and 172 are 4-year rotations of fallow, winter wheat on fallow, corn on spring plowing, and oats on disked cornland. The difference between them is that the fallow in rotation No. 172 is manured and that in No. 118 not manured. Rotations Nos. 171 and 119 are similar 4-year rotations in which oats are on fallow, corn on spring plowing, and winter wheat on disked cornland. The difference in these rotations is that fallow is manured in rotation No. 171, while in No. 119 it is not manured.

The annual and average yields of winter wheat and oats following manured and unmanured fallow in these rotations are shown in Table 8. No increase in the yield on manured fallow over that which was not manured has occurred. In rotation No. 38, which is alternate winter wheat and manured fallow, the yield was more than 3 bushels below that of plats $\mathrm{C}$ and $\mathrm{D}$, which are alternate winter wheat and fallow without manure. This difference may be due in part to differences in winterkilling, as these rotations are located some distance apart in the field. In 1922 grasshoppers took the crop in rotation No. 38, so that year is not included in the average of rotation 38 and of plats $\mathrm{C}$ and $\mathrm{D}$ with which it is compared. The winter-wheat yields in rotations Nos. 172 and 118 were about equal, showing practically no effect from the application of manure in No. 172.

TABLE 8.-Annual and average yields of winter wheat and oats on manured and unmanured fallow, 1917 to 1923, inclusive

\begin{tabular}{|c|c|c|c|c|c|c|c|c|c|}
\hline \multirow{2}{*}{ Crop and treatment } & \multirow{2}{*}{ Rotation } & \multicolumn{8}{|c|}{ Yields per acre (bushels) } \\
\hline & & 1917 & 1918 & 1919 & $1920^{1}$ & 1921 & $1922^{1}$ & $1923^{1}$ & $\begin{array}{c}\text { Aver- } \\
\text { age }\end{array}$ \\
\hline Winter wheat $\left\{\begin{array}{l}\text { Manured } \\
\text { Unmanured } \\
\text { Manured } \\
\text { Unmanured }\left\{\begin{array}{l}\text { Manured } \\
\text { Unmanured }\end{array}\right.\end{array}\right.$ & $\begin{array}{r}38 \\
\mathrm{MCC} \text { or D } \\
172 \\
118 \\
171 \\
119\end{array}$ & $\begin{array}{r}8.2 \\
10.0 \\
12.5 \\
11.8 \\
21.6 \\
25.6\end{array}$ & $\begin{aligned} 7.2 \\
8.2 \\
8.3 \\
11.3 \\
9.7 \\
10.9\end{aligned}$ & $\begin{array}{l}0 \\
3.5 \\
2.8 \\
1.8 \\
3.4 \\
3.1\end{array}$ & 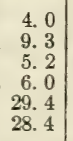 & $\begin{array}{l}11.0 \\
19.0 \\
19.3 \\
14.8 \\
43.4 \\
35.3\end{array}$ & $\begin{array}{r}0 \\
14.5 \\
9.8 \\
10.7 \\
19.7 \\
28.8\end{array}$ & $\begin{array}{c}0 \\
0 \\
0 \\
0 \\
35.0 \\
33.8\end{array}$ & $\begin{array}{r}25.1 \\
28.3 \\
8.3 \\
8.1 \\
23.2 \\
23.7\end{array}$ \\
\hline
\end{tabular}

1 Winter wheat winterkilled in 1920 and 1922 and was reseeded to Marquis in the spring. In 1923 it partly winterkilled and was reseeded to Marquis, but the plats were too weedy to harvest.

2 A verage for six years, not including 1922 , when the wheat in rotation 38 was destroyed by grasshoppers.

The average yield of oats in rotation No. 171, which receives an application of manure, was slightly less than in No. 119, which is not manured.

The application of manure before plowing the land has not increased the yields of small grains above those on fallow unmanured. In each case manuring has slightly decreased the yields. These results may change as the plats age or under more favorable climatic 
conditions than have prevailed during the seven years under study. The figures given are only for the year immediately following the fallow and do not compare the yields of the third and fourth crops in rotations Nos. 118, 119, 171, and 172 .

\section{WATER STORED DURING THE FALLOW PERIOD}

Soil-moisture determinations were made each year from 1917 to 1923, inclusive, on the two plats that are alternately fallowed and cropped to spring wheat. From these determinations the increase in the water content of the soil between harvest and the following seeding date can be calculated. This is approximately 21 months when the land is fallowed and is here called the fallow period. The soil samples were not always taken on the exact harvest and seeding dates, but with the exception of 1918, when the harvest sampling was delayed until December, they were taken within a few days of these dates.

Samples were taken in 1-foot sections to a depth of 6 feet with a tube 20 millimeters in diameter. As the determinations for the lower 3 feet show no appreciable changes in water content, the data from the surface 3 feet only are used in the present study. Four separate cores, or samples, were taken from as many different locations on each plat on each date. These were placed in two cans, the water content of each determined, and the percentage of water in the two averaged. The soil-moisture determinations for each foot were, therefore, the averages of four samples. The percentages of soil moisture were determined on the basis of dry weight. The weight of the soil per cubic foot was determined by calculation from the weight of the cores taken with the soil tube. The averages of large numbers of samples were used for these determinations, and it is believed that the volume weights determined by this method are fairly accurate. ${ }^{1}$

With the increase in the percentage of soil moisture and the weight per cubic foot of soil as known quantities, the increase in percentage is calculated as inches of water.

Table 9 presents detailed data regarding the quantity of water stored in the soil during five fallow periods between August 11, 1917, and May 21, 1923. This table gives the weight per cubic foot of soil, the date of the first determination (called harvest date), the date of the determination at or near seeding time (called seeding date), the percentage of water in each foot of soil on each of these dates, the increase in percentage between these dates, the equivalent in inches of this increase, the total increase in inches of water, the total precipitation during the period, and the percentage of the precipitation that was stored in the soil.

The total quantity of water stored in the soil varied from 1.77 inches for the period from August 11, 1917, to May 1, 1919, to 4.25 inches for the period from August 2, 1920, to May 22, 1922. The total precipitation from harvest to the following seeding date varied from 11.60 to 20.46 inches. The percentage of the precipitation that was stored in the soil varied from 10.1 to 22.8 .

\footnotetext{
1 Cole, John S., and Mathews, O R. Use of water by spring wheat on the Great Plains. U. S. Dept. Agr. Bul. 1004, 34 p., 10 figs. 1923.
} 
TABLE 9.-Percentage of water in the first 3 feet of soil at the beginning and end of the failow period, increase in percentage, the precipitation, and the percentage of the total precipitation stored in the soil for five fallow periods

\begin{tabular}{|c|c|c|c|c|c|c|c|c|c|c|c|}
\hline \multirow{2}{*}{ Plat } & \multirow{2}{*}{ Depth } & \multirow{2}{*}{$\begin{array}{c}\text { Weight } \\
\text { of soil } \\
\text { per } \\
\text { cubic } \\
\text { foot }\end{array}$} & \multicolumn{2}{|c|}{ Harvest } & \multicolumn{2}{|c|}{ Seeding } & \multirow{2}{*}{\multicolumn{2}{|c|}{ Increase }} & \multirow{2}{*}{$\begin{array}{l}\text { Total } \\
\text { water } \\
\text { stored }\end{array}$} & \multicolumn{2}{|c|}{ Precipitation } \\
\hline & & & Date & $\begin{array}{l}\text { Water } \\
\text { in soil }\end{array}$ & Date & $\begin{array}{l}\text { Water } \\
\text { in soil }\end{array}$ & & & & Total & Stored \\
\hline D. & $\left\{\begin{array}{r}\text { Feet } \\
1 \\
2 \\
3\end{array}\right.$ & $\begin{array}{c}\text { Pounds } \\
62 \\
86 \\
93\end{array}$ & Aug. 11, 1917 & $\begin{array}{r}\text { Per } \\
\text { cent } \\
7.3 \\
7.3 \\
10.0\end{array}$ & May 1,1919 & $\begin{array}{l}\text { Per } \\
\text { cent } \\
12.0 \\
12.8 \\
11.7\end{array}$ & $\begin{array}{r}\text { Per } \\
\text { cent } \\
4.7 \\
5.5 \\
1.7\end{array}$ & $\begin{array}{c}\text { Inches } \\
0.56 \\
.91 \\
.30\end{array}$ & $\left\{\begin{array}{l}\text { Inches } \\
1.77\end{array}\right.$ & $\begin{array}{l}\text { Inches } \\
17.58\end{array}$ & $\begin{array}{l}\text { Per } \\
\text { cent } \\
10.1\end{array}$ \\
\hline C. & $\begin{array}{l}1 \\
2 \\
3\end{array}$ & $\begin{array}{l}62 \\
86 \\
93\end{array}$ & 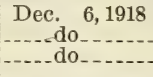 & $\begin{array}{r}12.0 \\
8.0 \\
8.4\end{array}$ & May 18,1920 & $\begin{array}{l}\text { 19. } 1 \\
16.1 \\
10.9\end{array}$ & $\begin{array}{l}7.1 \\
8.1 \\
2.5\end{array}$ & $\begin{array}{r}.85 \\
1.34 \\
.45\end{array}$ & 2. 64 & 11.60 & 22.8 \\
\hline D. & $\begin{array}{l}1 \\
2 \\
3\end{array}$ & $\begin{array}{l}62 \\
86 \\
93\end{array}$ & 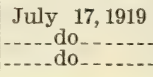 & $\begin{array}{l}\text { 6. } 2 \\
7.1 \\
9.3\end{array}$ & 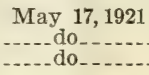 & $\begin{array}{l}17.3 \\
18.8 \\
12.6\end{array}$ & $\begin{array}{r}11.1 \\
11.7 \\
3.3\end{array}$ & $\begin{array}{r}1.32 \\
1.94 \\
.59\end{array}$ & 3. 85 & 18.46 & 20.9 \\
\hline C.. & $\begin{array}{l}1 \\
2 \\
3\end{array}$ & $\begin{array}{l}62 \\
86 \\
93\end{array}$ & Aug. 2,1920 & $\begin{array}{l}6.1 \\
7.4 \\
7.8\end{array}$ & May 22,1922 & $\begin{array}{l}17.3 \\
18.5 \\
13.8\end{array}$ & $\begin{array}{r}11.2 \\
11.1 \\
6.0\end{array}$ & $\begin{array}{l}1.34 \\
1.84 \\
1.07\end{array}$ & 4. 25 & 20.46 & 20.8 \\
\hline D. & $\begin{array}{l}1 \\
2 \\
3\end{array}$ & $\begin{array}{l}62 \\
86 \\
93\end{array}$ & 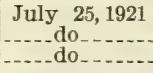 & $\begin{array}{l}6.6 \\
7.9 \\
8.5\end{array}$ & May 21,1923 & $\begin{array}{l}15.3 \\
16.0 \\
10.9\end{array}$ & $\begin{array}{l}8.7 \\
8.1 \\
2.4\end{array}$ & $\begin{array}{r}1.04 \\
1.34 \\
.43\end{array}$ & 2.81 & 16.46 & 17.1 \\
\hline
\end{tabular}

\section{SUMMARY}

This is a report of progress of experiments that are being continued with fallow and other methods of cultivation at the Assinniboine Field Station, near Havre, Mont. It covers a series of unfavorable seasons, and the yields reported are probably the lowest rather than the averages to be expected from this section.

The precipitation for the 7 years covered by this report was below normal. The 44-year normal precipitation for the 5 months from April to August, inclusive, is 8.58 inches, whereas the average precipitation for these months for the 7 years from 1917 to 1923, inclusive, was 7.17 inches. The precipitation in 1923, which is included in this average, was much above normal, but the advantage that might have been gained from the heary rains of June and July was offset by the very unfavorable conditions of April and May. The precipitation in June, which is a very critical month for small grains, was below the 44-year normal in 6 years of the 7 .

The yields of small grain averaged higher on fallow than on disked corn ground or with continuous cropping to small grain. The average yields from disked cornland were approximately intermediate between those from continuous small grain and those from fallow. Yields on corn ground were higher than those on fallow in 1919, which was the year of lowest yields. Yields of wheat in 1922 and of oats in 1918 on continuous cropping were slightly higher than on disked corn ground.

The total yields of corn (stover and grain) from fallow were approximately 1,000 pounds more than with any one of the three best methods of continuous corn growing, but corn grown continuously on spring plowing, fall plowing, or subsoiling was produced more economically than that grown on fallow. Spring listing for continuous corn was the lowest yielding method under trial. 
The yields of oats and winter wheat after green-manure crops were approximately half those after fallow. The average yields after field peas as a green-manure crop were slightly more than those following either winter rye or sweet clover as green manures. Yields immediately following green-manure crops were much less profitable than those from fallow.

The yield of winter wheat has averaged about the same from fallow plowed in the fall and left rough the first winter as from that plowed in May. Fallow plowed in the fall and immediately cultivated gave lighter yields than that plowed in the fall and left rough the first winter. Fallow plowed in July showed consistently lighter yields than that plowed in May.

Plowing 8 inches deep for fallow was more profitable with oats, barley, and winter wheat than plowing 4 inches deep or plowing 8 inches and subsoiling to 18 inches. Subsoiling gave higher yields of oats than 8-inch plowing, but the increase in yield was not enough to pay the additional cost of preparation. Winterkilling made the results with winter wheat unsatisfactory.

An application of barnyard manure before plowing for fallow has not increased the yield of either winter wheat or oats.

For spring wheat the fallow period from harvest until the following seeding date is between 20 and 21 months. The total precipitation for this period varied from 11.60 to 20.46 inches. The water stored in the surface 3 feet of soil varied from 1.77 to 4.25 inches. The percentage of the precipitation stored in the soil varied from 10.1 to 22.8 . 


\section{ORGANIZATION OF THE UNITED STATES DEPARTMENT OF AGRICULTURE}

December 29, 1924

Secretary of Agriculture Howard M. Gore.

Assistant Secretary

Director of Scientific Work

E. D. BALL.

Director of Regulatory Work

Walter G. Campbeli.

Director of Extension Work

C. W. WARBURTON.

Solicitor

R. W. Williams.

Weather Bureau

Charles F. Marvin, Chief.

Bureau of Agricultural Economics........ Henry C. TAylor, Chief.

Bureau of Animal Industry........... John R. Moнler, Chief.

Bureau of Plant Industry............ William A. Taylor, Chief.

Forest Service _... W. B. Greeley, Chief.

Bureau of Chemistry ......... C. A. Browne, Chief.

Bureau of Soils...................... Milton Whitney, Chief.

Bureau of Entomology............. How ARD, Chief.

Bureau of Biological Survey............. E. W. Nelson, Chief.

Bureau of Public Roads.............. Thomas H. MacDonald, Chief.

Bureau of Home Economics.............. Lovise Stanley, Chief.

Bureau of Dairying...................... C.

Fixed Nitrogen Research Laboratory........ F. G. Cottrell, Director.

Office of Experiment Stations_.......... E. W. Allen, Chief.

Office of Cooperative Extension Work ....... C. B. Sмгтн, Chief.

Office of Publications....................... Haynes, Director.

Library . . . . . . Claribel R. Barnett, Librarian.

Federal Horticultural Board_........... C. L. Marlatt, Chairman.

Insecticide and Fungicide Board.......... J. K. HAYwood, Chairman.

Packers and Stockyards Administration....-_ Chester Morrill, Assistant to the

Grain Futures Administration............ Secretary.

This bulletin is a contribution from

Bureau of Plant Industry............ William A. Taylor, Chief. Office of Dry-Land Agriculture Investigations............................. 16

E. C. Chilcotт, in Charge.

ADDITIONAL COPIES

OF THIS PUBLICATION MAY BE PROCURED FROM THE SUPERINTENDENT OF DOCUMENTS GOVERNMENT PRINTING OFFICE WASHINGTON, D.C. AT 5 CENTS PER COPY 

